ESJ Social Sciences

\title{
The Role of Social Capital in the Employability of University Graduates in Zambia: A Case of University of Zambia Graduates
}

\author{
Eliphas Machacha, PhD \\ The University of Zambia, School of Humanities and Social Sciences, \\ Department of Social Work and Sociology, Lusaka, Zambia
}

Doi:10.19044/esj.2021.v17n35p111

Submitted: 12 October 2021

Accepted: 26 October 2021

Published: 31 October 2021
Copyright 2021 Author(s)

Under Creative Commons BY-NC-ND

4.0 OPEN ACCESS

Cite As:

Machacha E. (2021). The Role of Social Capital in the Employability of University Graduates in Zambia: A Case of University of Zambia Graduates. European Scientific Journal, ESJ, 17 (35), 111. https://doi.org/10.19044/esj.2021.v17n35p111

\section{Abstract}

The research presented in this paper was designed to investigate the role of social capital in the employability of University Graduates in Zambia: A Case of University of Zambia Graduates. The study focused on the period between the years 2000 and 2015. In this study social capital was operationalised as social connections that can be used in search of jobs. Employability was operationalised as the ability to get employed or get a job. This research used a sequential mixed method research design to investigate the research problem. The study was carried out in the City of Lusaka. 208 University of Graduates and 16 employers participated in this study. Data were collected using a questionnaire and interviews. Statistical Package for Social Sciences (SPSS) was used in the management and analysis of quantitative data while thematic analysis was applied in the analysis of qualitative data. The results from this study indicated that UNZA Graduates attach a lot of importance to the use of social connections in search of job opportunities in the labour market. However, only powerful social connections were effective in this process and were not available to everyone. The results also revealed that social connections through relatives and close friends were more effective in their employability than social connections through acquaintances and potential employers. In conclusion, this study showed that social connections 
facilitated by relatives and close friends through people of influence in society were more effective but, to a large extent, they depend on one's social status.

Keywords: University Graduates, labour market, social capital, employability, social connections

\section{Introduction}

This research study was designed to investigate the role of social capital in the employability of University of Zambia (UNZA) Graduates in Zambia. The study focused on graduates who graduated from the University of Zambia between the years 2000 and 2015 inclusive. The rationale for targeting the period between the years 2000 and 2015 was based on the following reasons. First, according to official statistics, formal employment in Zambia had declined to just about $10 \%$ of the labour force in 2001 from approximately $75 \%$ in 1975 largely due to the privatisation programme which was embarked on by the new Government of the Movement for Multiparty Democracy (MMD), as part of the market led reforms which they designed in the 1990s upon assuming office (AfDB/OECD, 2004). These MMD reforms included an initiative to slim down the oversized public service which led to massive losses of employment for many public service employees. During this same period the country experienced a further and steady decline in employment as many of the newly privatised companies started collapsing, while some of them started streamlining their labour force thereby pushing the number of the unemployed people higher (AfDB/OECD, 2004).

When there is a decline in the size of the labour market, the situation leads to a scramble for a few job opportunities that may be available against thousands and thousands of job seekers. So in order to beat the competition, many job seekers may resort to the use of alternative methods to get employed. Such methods may involve the use of social capital. In particular, the impact of graduates' social capital, which is generated through social connections or social networks, on the job search process is the single research gap most in need of filling up in the research agenda of labour market scholars in the world, and the Zambian context. According to sociological literature social capital is understood as "networks or social connections that are governed by shared norms, values, social obligations, exchanges and understandings that facilitate co-operation within or among groups of people" (Halpern, 2005). The understanding of how social capital works is an important concern for sociological inquiry. Questions concerning how people find jobs and how vacancies are filled are claimed to be among the most under-researched topics within the labour market analyses. In the case of employability as a variable of interest for this study, it is argued that graduate employability is more than just being able to find a job immediately after graduation, rather employability 
refers to the acquisition of personal attributes and achievements such as knowledge, skills, resourcefulness, resilience and abilities that make graduates more likely to be successful in gaining employment or their chosen occupations, whether paid employment or self-employment (The UK Quality Assurance Agency, 2019).

Politically, Zambia is considered a stable country with successful democratic elections held every five years. Zambia's political stability can be assessed in terms of the number of times the country has ushered in new governments peacefully and democratically. According to the 2012 and 2017 Zambia Labour Force Surveys (CSO, 2012; 2017), which were conducted by the Central Statistical Office, the political and socio-economic data indicates that Zambia became independent from the British Colonial government on $24^{\text {th }}$ October, 1964. On this day, the United National Independence Party (UNIP) under the leadership of Dr. Kenneth David Kaunda was ushered in and formed the first Government of the Republic of Zambia. Geographically, Zambia is a landlocked country in Southern Africa. It covers a total area of 752,612 square kilometres, located between latitudes $8^{\circ}$ and $18^{\circ}$ south and longitudes $22^{\circ}$ and $34^{\circ}$ east. Its neighbours include the Democratic Republic of Congo to the north, Tanzania to the north-east, Malawi to the east, Mozambique, Zimbabwe, Botswana and Namibia to the south and Angola to the west (CSO, 2018).

\section{University Education and the Labour Market}

The value of a university degree, at least when it comes to finding a job, is not unique to any country anywhere in the world. According to Hamermesh (2011), an international labour economist, argued that there is a correlation between a university degree and the likelihood of finding a job which can be seen around the world. However, exactly how much university credentials pay off differs from country to country. In the case of Zambia, as extant literature on the political and socio-economic events of the 1990s through to 2000 in Zambia shows, these events caused far-reaching changes in both higher education and the labour market, which fundamentally altered university graduates' relationships with the labour market and the structure of opportunities available to them. For instance, more universities were opened up during this period to operate and offer degree programmes alongside the oldest universities in the country, namely the University of Zambia and the Copperbelt University, this development translated into more university graduates being offloaded onto the declining labour market in Zambia (Culkins, 2013).

It is overwhelmingly believed that finding a first job or simply changing jobs should be relatively easy for people with university education, because a university degree lends an advantage to job seekers who possess it 
over those that do not (Hamermesh, 2011). The labour market entry should be comparatively smooth for such a group of people, as they are deemed to be well qualified (Blossfeld et al, 2008). However, this picture could not be said to be the same for university graduates in Zambia. In Zambia, the decline in the labour market began towards the end of the Presidency of Dr. Kenneth Kaunda, mid 1980s and the trend peaked in the 1990s, and eventually leading to Mr. Fredrick Chiluba taking over as President of the Republic of Zambia in 1991 (ILO, 2008); this trend has continued to date. Competition for jobs in Zambia, like everywhere else in the world, has become intense leading to a widely held notion that university education is no longer a passport to secure employment for the $21^{\text {st }}$ century graduates. Globally, the number of new graduates is increasing, while available jobs are fewer (Nabi and Holden, 2008). Given a situation like this, one would argue that whilst upward mobility for university graduates depends crucially on their educational qualifications, 'other resources may be available to help them get employed in the labour market' (Goldthorpe and Jackson, 2008). Therefore, understanding 'other resources' or factors that enhance chances of university graduates, University of Zambia graduates included, getting employed in the labour market becomes vital. The point of interest here is that 'other resources,' rather than their educational qualifications may be available to help university graduates successfully land job opportunities in the labour market (Goldthorpe and Jackson, 2008). Such 'other resources' could refer to social capital. Conventional wisdom, born out of experience, informs us that close competition for jobs and contracts are usually won by those with friends in high places (Woolcock, 1998).

\section{Research Problem and Aim of the Study}

The extensive review of extant literature on social capital and the labour market revealed a dearth of prior studies on the role of social capital in the employability of university graduates in Africa in general, and Zambia in particular. Therefore, the aim of this study was to investigate the role of social capital in the employability of University of Zambia graduates in the labour market in Zambia by focusing on the type of job search methods they use in finding jobs and to learn whether or not social capital plays any influence in their endeavour to find jobs.

\section{Literature Review \\ Theoretical Review}

This section presents a short and concise theoretical framework of this study. A theoretical framework is the 'blueprint' or guide for a research (Grant and Osanloo, 2014). It is a framework based on an existing theory in a field of inquiry that is related and/or reflects the hypothetical position of a study. It is 
a blueprint that is often 'borrowed' by the researcher to build his/her own house or research inquiry. The theory within which this study was embedded and conducted was the social capital theory. This theory explains social connections, based on social obligations, social norms, values and exchanges among actors and how these practices contribute to one's success in life. Social capital is embedded in a set of socially situated and culturally defined relations (Portes and Alejandro, 1998; Putnam, 2002; Lin, 2008).

The theoretical review of literature on social capital reveals that there are three forms of social capital that have been proposed. These include bonding, linking, and bridging social capital (Lin, 2008; McGonigal, 2007; Woolcock and Narayan, 2000):

Bonding social capital refers to the interaction between similar types of people such as family members and close personal friends. It links to people based on a sense of common identity ("people like us") such as family, close friends and people who share the same culture or ethnicity.

Bridging social capital is a type of social capital that describes connections that link people across a cleavage that typically divides society (such as race, or class, or religion). Bridging social capital is different from bonding social capital, which is within social groups and is characterised by dense networks with people feeling a sense of shared identity and belonging where bridging social capital links people that are not very close to one another such as acquaintances or distant friends.

Linking social capital refers to connections with organisations and institutions and assists in accruing support from people in authority. For instance, active membership of social, education, political, religious, and voluntary organisations may contribute to an individual's social capital.

Therefore, human interaction results in social connections - social networks - that work to make life more fulfilling and that make our economic efforts more productive. These social connections are critical in our social world and they range from micro or small groups to large scale bureaucratic organisations (Ballantine, 2006). Social capital, then, is the value that is derived from belonging to networks, based on the idea that access to resources is cultivated through connections among and between people. The social connections that develop networks are built up over time through repeated exchanges (of information, emotions, or favours) and are linked to other forms of capital. In contrast, reductions in levels of social capital may contribute to feelings of disconnectedness and loss of trust, control, autonomy, and belonging. Social capital is, at least for Coleman and Putnam, a good thing: it can be transformed into all kinds of resources, from jobs to information to better health (Briggs, 2007). 


\section{Empirical Review}

Over the past several decades, researchers have attempted to determine and understand through rigorous investigations the role of social capital in influencing people's successes and achievements in their lifetime, including finding jobs in the labour market. For instance, Granovetter (1973), in a random sample of professional, managerial and technical job changers, his proposition was confirmed in his study and also in many subsequent studies, that a substantial proportion of individuals find their jobs via their contacts with friends, relatives, colleagues, or acquaintances. One major missing link in this study, and in many others, was their omission of the level of educational qualifications of job seekers in their studies, which presumably is an important variable in as far as studying labour market processes is concerned. Matloob Piracha and a group of other researchers (2013), conducted a longitudinal study in which they analysed the role of social capital on immigrants' labour market outcomes in Australia. Their conclusion, just like Granovetter (1973), was that social capital works, and for Matloob (2013), social capital is particularly important for immigrants, but it only affects the probability of getting a white-collar job. Once again, there was no reference to educational levels of the research subjects so as to check their influence in finding such jobs in the labour market. In the same vein, a study by Bartus, Tamás (1998) also discovered, through a longitudinal and cross-sectional study, a positive relationship between social capital and getting a good job among secondary school leavers in Hungary. But of course, one would argue that this category of job seekers may indeed rely more on social capital to find jobs in the labour markets than their educational qualifications compared to university graduates who, probably may not need such 'other resource' to assist them in getting a job, because they are probably adequately qualified to obtain any job that suits them on merit compared to secondary school leavers.

In the African context, a review of extant literature on the role of social capital in the employment of job seekers in Africa revealed a dearth of prior studies on this subject. However, this researcher was able to find a few studies which this researcher could relate to, on social capital, that had been done in Africa. For instance, Anthony Gewer (2009) carried out a study in South Africa for his $\mathrm{PhD}$ on the features of social capital that enhance the employment outcomes of Further Education Training Colleges (FET) in 2009, in which he sought to problematise the notions of bonding and bridging social capital in the South African context and understand how social capital operates for young people who pass through the FET College system. This study reported that personal networks were critical in the employment of young people in South Africa, but they tend to be ineffective in impoverished environments for finding meaningful employment on initial entry into the 
labour market. This had a potential to further entrench social inequality in the country.

Similarly, in West Africa, Christophe J. Nordman and Laure PasquierDoumer (2014) in their study on the role of Family Networks in transitions in West African Labour Markets in Ouagadougou, Burkina Faso, in 2014, endeavoured to shed light on the role of family networks in the dynamics of workers on the labour market of a West African country. The main issue which was tackled in this research was the extent to which one's network was essential in labour market transitions, in particular from unemployment to employment. In their findings they learned that family networks had a significant effect on the dynamics of workers in the labour market and that this effect differs, depending on the type of transition and the considered dimension of the family network. The network size appeared to not matter much in the labour market dynamics. Strong ties, however, played a stabilising role by limiting large transitions. Their negative effect on transitions is reinforced with high levels of resources embedded in the network. In the Zambian context, Moonga Mumba for his $\mathrm{PhD}$ in 2014, conducted a study on the role of informal networks in youth self-employment in Zambia, in which he analysed the role of informal networks and learned how different informal connections help the self-employed youth access different business related resources such as information, finances, skills, customers and space. In his conclusion, the researcher stated that there tended to be a dominant reliance on strong ties (mostly one's family and friends) among the self-employed youth, as the main source of support.

In conclusion, the evaluation of data from the reviewed extant literature on social capital and the labour market shows that there is no concrete information on how individuals graduating from universities might or might not entirely rely on their educational qualifications to get jobs in the labour market. The question that arises from the literature is, besides their educational qualifications from university; how do university graduates use social capital (understood as social connections) to find jobs in the labour market? In addition, the review of literature in this paper has to a large extent established that most of the research studies that have already been carried out on social capital and the labour market have been done in developed countries, focusing particularly on migrants in the United States of America, Europe and Australia. However, there is a lack of empirical data on how, specifically, university graduates may rely on social capital other than their education to find jobs in the labour market, particularly in the context of developing countries, such as Zambia. 


\section{Research Methodology \\ Research Goals and Research Questions}

This research had two goals: the first and main goal was to investigate if there was any relationship between social capital and the prospects of finding a job in the labour market among University of Zambia Graduates in Zambia. The second goal of this research was to contribute to the discussion of the theory and the forms or dimensions of social capital as a concept. Therefore, in addressing these research goals, the research protocol was designed as follows.

\section{Location of Study Area}

This study was conducted in the City of Lusaka in Lusaka Province of Zambia: The selection of this study area was based on the understanding that the labour market in Zambia is larger and concentrated in large cities like Lusaka City. It is generally understood that cities are usually the centres of economic activities and opportunities.

Figure 1: Map of Zambia

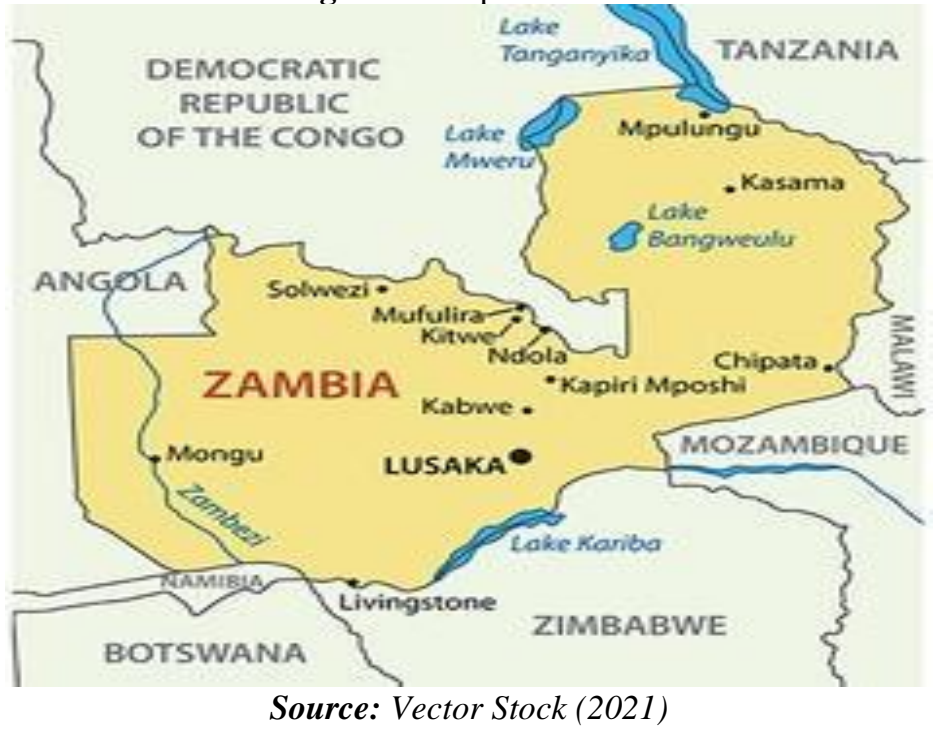

\section{Research Design}

This study employed the sequential mixed method research design with a bias towards quantitative data. According to Bryman (2012), a research design represents a structure that guides the execution of a research method or a set of research methods and the analysis of the subsequent data. Consequently, this study employed both quantitative and qualitative methods in addressing the research problem. Using a mixed methodology can help understand the research problem in greater depth. It can help increase confidence in the findings, providing more evidence while offsetting possible 
shortcomings from using a single approach. Whereas undertaking research using mixed methodology can be time consuming it can help to address broader questions adding insight that could otherwise have been missed (Creswell, 2007).

\section{Study Population}

The study population included male and female University of Zambia (UNZA) students who graduated between 2000 and 2015 inclusive, from the nine Schools which make up the University of Zambia, across all fields of study that are offered at the University; who were resident in the city of Lusaka; and who were in formal employment at the time of the study. Focusing on university graduates provided the study with an advantage of satisfying the requirement of increasing statistical strength of the research in the sense that university graduates have similar characteristics with respect to human capital such as number of years spent in the university and labour market experiences, and demographic characteristics (age, marital status).

\section{Sample Size and Sampling Technique}

208 study participants who included male and female University of Zambia (UNZA) students who graduated between 2000 and 2015; from the nine Schools which make up the University of Zambia; across all fields of study that are offered at the University; resident in the city of Lusaka; and who were in formal employment at the time of the study were randomly sampled using the university alumni register as a sampling frame, which was sorted out in Microsoft excel. In addition to University graduates, 16 employers were purposefully picked for in-depth interviews.

\section{Data Collection, Management and Analysis}

The type of data that were collected in this research included both quantitative and qualitative data (QUANT + qual.) by using a questionnaire for University Graduates and in-depth interviews for employers. Quantitative data were managed and analysed using Statistical Package for Social Sciences (SPSS), which enabled this researcher to generate descriptive statistics, summarised and presented in tabular and graphical forms. In the case of qualitative data, thematic analysis (TA) was used in which themes were generated from transcribed data obtained from key informants (employers).

\section{Positionality and Reflexivity}

In dealing with key informants (employers) for qualitative data in this study, this researcher recognised the fact that being a University of Zambia (UNZA) Graduate himself, he was part of the subjects he was studying (University of Zambia Graduates). And also the fact that he is an employee of 
the University of Zambia, he was aware that his ontological and epistemological beliefs on the employability of University of Zambia Graduates could influence this research in terms of his personal values, beliefs and opinion about the employability of UNZA Graduates.

\section{Findings and Discussion \\ Demographic characteristics of Study participants}

The findings show that the overall response rate was $100 \%$ owing to the fact that non-responses were being replaced with the readily available sample units on the sampling frame. The findings also revealed that there were more male participants in the study who represented about $66 \%$ of the sample than female participants who represented about $34 \%$ of the sample. The average age of the respondents was just slightly below 30 years, and more than half of the participants, about 55\%, were single and had never married before at the time the survey was being carried out. About $41 \%$ were either married or engaged to be married or were cohabiting. On the question of whether or not they had any children, about $74 \%$ reported to have no children while $26 \%$ reported to have children at the time of the study. These demographic variables indicate the degree of family responsibility and economic dependence which may have affected the respondents' job search activity in the labour market. The survey reveals that the majority of study participants (about 79\%) graduated from the University of Zambia in the years from 2011 to 2015, and about $21 \%$ in the years from 2001 to 2010 . The majority (54\%) of the graduates obtained their Degrees in the Arts-based fields of study from the School of Humanities and Social Sciences, and School of Education. This number of graduates in the Arts-based fields of study also caters for those who graduated from the Institute of Distance Education (IDE).

In terms of their parents' educational levels, more than half (53\%) of the participants in the sample had a father with higher education, that is, either college education or university education, while about $33 \%$ of the participants in the sample had a mother with higher education, either college education or university education. It can be seen here that the educational level among mothers is obviously increasing in the current generation, reflecting the increase in study rates among females than in previous generations. 
Table 1: Demographic profile of respondents $(\mathrm{N}=208)$

\begin{tabular}{|c|c|c|c|}
\hline Variable & Index & Frequency & Percentage \\
\hline Sex & $\begin{array}{l}\text { Male } \\
\text { Female }\end{array}$ & $\begin{array}{l}138 \\
70\end{array}$ & $\begin{array}{l}66 \\
34\end{array}$ \\
\hline Age & $\begin{array}{l}20-24 \\
25-29 \\
30-34 \\
35-39 \\
40-44 \\
\text { No Response }\end{array}$ & $\begin{array}{l}13 \\
133 \\
34 \\
18 \\
7 \\
3\end{array}$ & $\begin{array}{l}6.3 \\
63.9 \\
16.3 \\
8.7 \\
3.4 \\
1.4\end{array}$ \\
\hline Area of residence & $\begin{array}{l}\text { High Cost } \\
\text { Medium Cost } \\
\text { Low Cost } \\
\text { No Response }\end{array}$ & $\begin{array}{l}60 \\
130 \\
16 \\
2\end{array}$ & $\begin{array}{l}28.8 \\
62.5 \\
7.7 \\
1\end{array}$ \\
\hline Degree obtained & $\begin{array}{l}\text { Bachelor's Degree } \\
\text { Master's Degree } \\
\text { PhD }\end{array}$ & $\begin{array}{l}202 \\
6 \\
0\end{array}$ & $\begin{array}{l}97.1 \\
2.9 \\
0\end{array}$ \\
\hline Year graduated & $\begin{array}{l}2001-2005 \\
2006-2010 \\
2011-2015\end{array}$ & $\begin{array}{l}17 \\
28 \\
163\end{array}$ & $\begin{array}{l}8.2 \\
13.4 \\
78.5\end{array}$ \\
\hline Study Programmes & $\begin{array}{l}\text { Arts/Humanities } \\
\text { BA (Edu) } \\
\text { BALIS } \\
\text { BSc (Agric.) } \\
\text { BSc (Edu) } \\
\text { BSc (Eng.) } \\
\text { BSc (Env. Health) } \\
\text { BSc (Med.) } \\
\text { LLB }\end{array}$ & $\begin{array}{l}112 \\
30 \\
15 \\
6 \\
20 \\
9 \\
8 \\
5 \\
3\end{array}$ & $\begin{array}{l}53.8 \\
14.4 \\
7.2 \\
2.9 \\
9.6 \\
4.3 \\
3.9 \\
2.4 \\
1.4\end{array}$ \\
\hline Marital status & $\begin{array}{l}\text { Married } \\
\text { Engaged } \\
\text { Cohabiting } \\
\text { Never married } \\
\text { Separated } \\
\text { Divorced } \\
\text { No Response }\end{array}$ & $\begin{array}{l}59 \\
21 \\
5 \\
114 \\
7 \\
1 \\
1\end{array}$ & $\begin{array}{l}28.4 \\
10.1 \\
2.4 \\
54.8 \\
3.4 \\
0.5 \\
0.5\end{array}$ \\
\hline Do you have children & $\begin{array}{l}\text { Yes } \\
\text { No }\end{array}$ & $\begin{array}{l}55 \\
153 \\
\end{array}$ & $\begin{array}{l}26.4 \\
73.6\end{array}$ \\
\hline
\end{tabular}

Key: Arts = Bachelor of Arts (Social Sciences); Humanities = Literature and Languages; BA $(E d u)=$ Bachelor of Arts with Education; BALIS = Bachelor of Arts in Library and Information Science; BSc (Agric.) = Bachelor of Agriculture Science/Agricultural Economics; BSc $(E d u)=$ Bachelor of Science with Education; BSc (Eng.) = Bachelor of Science in Engineering; BSc (Env. Health) = Bachelor of Environmental Health; BSc (Med) $=$ Bachelor of Medicine and Surgery; LLB = Bachelor of Laws

Source: Survey data (2018)

\section{Socio-economic characteristics of study participants}

The socio-economic situation of one's family can affect one's life chances in society. Therefore, in this study there was a provision for 
respondents to indicate their thinking of their family's socio-economic situation, this refers to the family which respondents were staying with at the time of the study. The data on the socio-economic situation are summarised as follows. The study revealed that $0.5 \%$ of the respondent indicated that they were poor ( 0 - 2 USD/Day), 5.3\% indicated that they were near poor (2 - 4 USD/Day), $27.9 \%$ of the respondents indicated that they were living in an emerging middle class (4 - 10 USD/Day), the majority (54.3\%) of the respondents indicated that they were living in middle class families $(10-20$ USD/Day), 8.6\% indicated that their families were in the upper class $(20+$ USD/Day), and 3.4\% of the respondents did not respond to the question.

\section{Employment Situation of Study participants}

In terms of the respondents' employment status at the time of the study, it was revealed that approximately $95.2 \%$ were in formal employment, with the Government of the Republic of Zambia (GRZ) and private institutions being the largest employers where most of them were doing office work as administrators and specialists. The figures are broken down as follows, 38.5\% of the respondents were employed by the Government of the Republic of Zambia (GRZ), 39.9\% were employed by the Private Institutions, 9.6\% were employed by Non-Governmental Organizations (NGOs), $1 \%$ of the respondents were Self-Employed, $7.2 \%$ were employed by the Religious Institutions, and 3.8\% did not respond to the question. Some of the respondents who did not respond to the question on their employment status at the time of the study are those who were already in employment while studying for their Degrees at the University of Zambia (UNZA).

On the question of their first formal employers after they finished their studies at UNZA, the largest number of respondents indicated institutions in the private sector as their first employer after they graduated from UNZA, the percentage standing at 53\% in the private sector, $28 \%$ in GRZ, and $13.5 \%$ in NGOs. In Zambia today, the Government of the Republic of Zambia (GRZ) is one of the largest employers of University Graduates. It became so following the massive privatisation of the parastatal sector beginning in the mid-1990s going into the 2000s by the Movement for Multiparty Democracy (MMD) government which had taken over from the United National Independence Party (UNIP) in 1991.

While the private sector expanded as a result of the privatisation process, the public sector which was dominated by parastatal companies (government owned companies) shrunk in size leaving the government as the major player in providing employment to University graduates. The fundamental role of the parastatal sector was to act as the main agent of the state in fostering economic development of the country (Turok, 1981). These state controlled companies, even though not obliged, undertook government- 
favoured programmes such as the training and employment of Zambians. Under such an arrangement, the labour market was relatively stable; it was a stability that was guaranteed by a considerable degree of central planning by the government involving the setting up of a large civil service as the government aimed at ensuring self-sufficiency. The parastatal sector was crucial to the government's employment creation and job security agenda. Zambians were guaranteed jobs as a way of tackling poverty via access to incomes. In the main, employment became a key development imperative and an artery of social policy. However, beginning in 1991 to 2001, the MMD government adopted a market-oriented economy under which they embarked on a massive privatisation of state-run companies and enterprises. Fredrick Chiluba's administration introduced a robust economic policy that focused on improving efficiency in both the public and private sectors through the creation of appropriate market conditions and implementation of marketenhancing policies. The cornerstone of this policy was liberalisation of the economy.

\section{Job Search Methods}

Labour market entrants are able to choose within a wide range of job search methods. They may send direct applications to employers, they may respond to job advertisements through various media such as newspapers, magazines, television, radio and internet, they may search through employment agencies, or utilise informal search methods such as connections through relatives, friends, acquaintances and potential employers. The results revealed that $34.1 \%$ of the respondents used social connections to obtained their first job, $26 \%$ indicated they made unsolicited or direct applications to obtain their first job, $13.5 \%$ said that they responded to Newspaper job advertisements to obtain their first job, $2.9 \%$ of the respondents responded to Television job advertisements to obtained their first job, $0.5 \%$ of the respondent responded to a Radio advertisement to obtain his/her first job, and another $0.5 \%$ indicated that they already had a job the time they were obtaining their Bachelor's Degree from UNZA, as shown table 1 below. 
Table 2: Methods Respondents used to get their first job

\begin{tabular}{|l|l|l|l|}
\hline Method of getting first full time job & Frequency & Percent \\
\hline & Through social connections & 71 & 34.1 \\
\hline Made unsolicited or direct applications & 54 & 26.0 \\
\cline { 2 - 4 } & Responded to Newspaper adverts & 28 & 13.5 \\
\cline { 2 - 3 } & 6 & 2.9 \\
\hline Responded to Television adverts & 1 & 0.5 \\
\hline Responded to Radio adverts & 1 & 0.5 \\
\hline I already had a job & 2 & 1.0 \\
\hline Campus interviews & 1 & 0.5 \\
\hline I was nominated by UNZA & 2 & 1.0 \\
\hline I was nominated by my School at UNZA & 15 & 7.2 \\
\hline I was nominated by Department at UNZA & 21 & 10.1 \\
\hline Job advert discovered through social media & 21 & 2.9 \\
\hline Through Internship & 6 & $\mathbf{1 0 0 . 0}$ \\
\hline
\end{tabular}

Source: Survey data (2021)

Furthermore, $1 \%$ of the respondents indicated that they attended campus interviews (conducted by their current employer on campus) to obtained their first job, $0.5 \%$ were nominated by UNZA to obtained their first job, $1 \%$ were nominated by their School at UNZA to obtained their first job, $7.2 \%$ were nominated by their Departments at UNZA to obtained their first job, $10.1 \%$ responded to a job advertisement through social media and the internet (such as Facebook; LinkedIn etc.) to obtain their first job, and 2.9\% of the respondents used internship to get their first job as shown above.

\section{How long it took find the first job}

Study participants were also asked to indicate the time it took them to find their formal employment after graduating from the University of Zambia. The study revealed that the majority of UNZA Graduates in the period under consideration took in the range of 7 to 12 months to land their first formal job (approximately $73 \%$ ), with about $1.5 \%$ outliers who indicated it took them about 3 and half years to get their formal job after graduating from UNZA. The approximately $73 \%$ who found their first job within seven to twelve months were falling within the normal range of the time that a job seeker is expected to find employment. Globally, labour market experts believe that it should take a job seeker approximately three to six months to land their first employment, of course after making many applications to various organisations (ILO, 2008). The implication of these findings was that, the Zambian labour market was still doing fairly well in the sense that it could absorb such a large number of graduates within a period of twelve months, even though the figure was not telling us anything about the quality of the jobs these UNZA Graduates were getting in that period. We could not categorically 
tell whether or not these jobs were commensurate with the educational qualifications of the graduates.

When it comes to their level of satisfaction with their current jobs at the time of the study, the results of the study show that $8.7 \%$ were very dissatisfied, $13 \%$ of respondents were dissatisfied, $27.4 \%$ were neither satisfied nor dissatisfied while $39.9 \%$ indicated that they were satisfied and $9.1 \%$ of the respondents were very satisfied. This means approximately half of the respondents, $49 \%$ were actually satisfied with their current jobs at the time of the study while $21.6 \%$ were not satisfied with their current jobs, $27.4 \%$ were undecided about their level of satisfaction or dissatisfaction with their jobs, $2 \%$ of the respondents did not respondent to the question on job satisfaction. The level of dissatisfaction can only be explained in a situation where such respondents had different educational backgrounds but had found themselves working in different professions or jobs. When there are fewer job opportunities in the labour market against hundreds of thousands of job seekers, job seekers become desperate to get a job and they end up getting any job opportunity that comes their way, this is what leads to job dissatisfaction in addition to other factors.

\section{Employers' views and experiences}

In this study interviews were conducted with a total of 16 employers from the public, private and Civil Society Organisations sectors. The employers consisted of people who are involved in the hiring of job applicants for job openings that fall vacant in their organisations. Six employers or their representatives were interviewed from public institutions, including parastatal companies (government owned corporations), and another six from private institutions while four interviewees were drawn from Civil Society Organisations. There were 10 males and 6 females, the average age of the informants was 35 years. In terms of the educational qualifications, 10 of them indicate a Bachelor's Degree as their highest level of qualifications while 6 indicate a Master's Degree as their highest level of qualifications.

\section{Recruitment and Selection Methods}

In the findings, almost all of the key informants revealed that the most popular methods of recruiting people, including UNZA Graduates, for job vacancies involve what are referred to as 'traditional' or 'formal' methods. The commonest method among these methods is the use of advertisement of job vacancies in the media (print and electronic media), and the most popular method is the newspaper advertisement. In addition to this long standing tradition of recruiting job applicants or job seekers, where there was special need in terms of human resource development, some employers indicated that they select certain tertiary institutions offering certain Degree programmes, 
and engage such institutions to select graduating students in specific fields of study to be employed in their organisations. After receiving applications from qualified applicants, the study discovered most employers use interviews as a method for selecting the most qualified individuals to fill up the vacancies. Some of them use interviews in combination with other techniques such as aptitude tests and other types of tests. Employers were also asked to indicate if factors such as social connections of job seekers, the gender of job applicants, UNZA Degree, and the type of university one attended play a role in the hiring of such job seekers or applicants.

"It is generally believed that nowadays job seekers rely on social connections with potential employers, either through friends or acquaintances or relatives to get employed in Zambia."

"We don't look at which university a person graduated from but we look at the competences an individual has in terms of knowledge and skills."

Furthermore, the findings revealed that many organisations are equal opportunity employers in as far as gender or sex of job seekers is concerned. Many organisations support people of all kinds of backgrounds regardless of their sex or gender.

"Gender or sex does not really matter when recruiting in my organisation. Equal opportunities are given to both males and females. What matters is one's qualifications. My organisation actually promotes gender parity

In interpreting these findings this researcher begins by first and foremost acknowledging that this study was the first of its kind in Zambia to study how University of Zambia Graduates in the current era can activate their social capital and make use of social connections, as part of what we can refer to as 'informal' job search methods, to find employment in the competitive labour market in the country. Social connections have always been a common feature among human beings for as long as humanity has existed on earth. People turn to social connections and activate them when faced with a challenge or a problem or a need which may require a solution from other people or when they are in a vulnerable position. Over the past several decades, researchers have attempted to determine and understand through rigorous investigations the role of social capital in influencing people's successes and achievements in their lifetime, including finding jobs in the labour market. This researcher has joined this group of researchers who have attempted to understand this social phenomenon.

We have learned in this study that the labour market is believed to be an employer-controlled process. It is the employer who demands that a 
curriculum vitae (CV) should be submitted by a job seeker, and decides when to hire, who to interview, and who not to interview, who to offer the job, and how much money to offer to the new employee. The employer, therefore, is always in the driver's seat in the labour market. It is a fact that the average job seeker in Zambia relies largely on his or her CV to find a job and subsequently may not be successful. One major reason is that the job seeker is competing with thousands of other job seekers. In such circumstances, the job seeker needs to be equally creative either in writing the $\mathrm{CV}$, or skip it altogether and become an aggressive job seeker.

Many studies have conceptualized the way people search for a job into two categories; that is "formal and informal" search methods. Formal job search methods are those that involve formal intermediaries such as the use of advertisements, employment agencies, college interviews and many others. Informal job search methods are those that do not involve formal intermediaries, but may be based on people's social relations with friends, relatives and employers (Wanberg et al, 2010). This study focused on the role that social connections play in the employability of University of Zambia Graduates in the 2000s era. These social connections can be created through families or friends or both, and they fall in the category of informal job search methods.

\section{Conclusion}

This study has attempted to answer a very common belief and aphorism among job seekers that finding a job in Zambia usually depends on one's social connections rather than one's qualifications. Findings of this study provided an account of the challenges university graduates experience while looking for employment and also provided a nuanced understanding of the levels of employability within the Zambia context. One of the most striking findings in this study across the economic divide was the belief in the power of social connections in helping job seekers to find jobs.

\section{References:}

1. AfDB/OECD (2004) African Economic Outlook: Income Poverty target in Sub-Saharan Africa. Paris: African Development Bank and OECD

2. Ballantine, J.H., (2006) Our Social World Condensed: Introduction to Sociology. Thousand Oaks: SAGE Publications

3. Bartus Tamás (1998) Social Capital and Earnings Inequalities: The Role of Informal Job Search in Hungary. Budapest.

4. Blossfeld, H.P. Buchholz, S., Bukodi, E. and Kurz, K. (2008) Young Workers, Globalization and the Labour Market. Comparing Early 
Working Life in Eleven Countries. Cheltenham, UK/Northampton, MA: Edward Elgar.

5. Briggs de Souza (2007) Social Capital and the Cities: Advice to Change Agents, National Civic Review 86(2):111 - 117

6. Bryman, A, (2012) Social Research Methods. Oxford: Oxford University Press

7. Central Statistical Office (2018) Labour Force Survey Report. Lusaka: $\mathrm{CSO}$

8. Central Statistical Office (2017) Labour Force Survey Report. Lusaka: $\mathrm{CSO}$

9. Central Statistical Office (2012) Labour Force Survey Report. Lusaka: $\mathrm{CSO}$

10. Creswell, J. W. (2007). Research design: Qualitative, Quantitative, and Mixed methods Approaches (2nd ed.). Thousand Oaks, CA: Sage.

11. Culkins, N., (2013) Beyond Being A Student: An Exploration of Student \& Graduate Start-Up's (SGSU's) Operating From University Incubators In Journal of Small Business and Enterprise development. 20, 3, p. 634-639

12. Gewer, A (2009) PhD Thesis, unpublished: Feature of Social Capital that Enhance the Employment Outcomes of FET College Learners. Johannesburg: University of Witwatersrand.

13. Goldthorpe, J.H. and Jackson, M. (2008) 'Problems of an EducationBased Meritocracy', in A. Lareau and D. Conley (eds.), Social Class. How Does it Work? Russell Sage Foundation Press.

14. Granovetter, M. (1995) [1974] Getting a Job: A Study of Contacts and Careers. Chicago: University of Chicago Press.

15. Granovetter, M. (1973) 'The strength of weak ties', American Journal of Sociology, 78, 6, 1360-80.

16. Grant, C. \& Osanloo, A., (2014) Understanding, Selecting, and Integrating a Theoretical Framework in Dissertation Research: Creating the Blueprint for 'House'. Administrative Issues Journal: Connecting Education, Practice and Research, Pp. 12-22

17. Halpern, D et al, (2005) Social Capital. Cambridge: Polity Press

18. Hamermesh, D. (2011) Beauty pays: Why attractive people are more successful. Texas: Princeton University Press.

19. ILO (2008) Decent Work Country profile: Zambia. Geneva: International Labour Office

20. Lin, N. (2008) 'A Network Theory of Social Capital', in J. Deth, D. Castiglione \& G. Wolleb (eds.), The handbook of social capital, 50-69. Oxford: Oxford University Press

21. Matloob, P, Massimiliano, T, Matias V, (2013) 'Social Capital and Immigrants’ Labour Market Performance, IZA DP No. 7274 
22. McGonigal, J. et al (2007) Social capital, social inclusion and changing school contexts: A Scottish perspective. British Journal of Educational Studies, 55(1), 77-94.

23. Mumba, H, M, (2014) PhD Thesis, unpublished: Informal Networks and Youth Self-Employment in Zambia. Lusaka: UNZA.

24. Nabi, G, \& Holden, R. (2008) Graduate entrepreneurship: Intentions, education and training. Education and Training, Vol. 50, No. 7, pp 545-551.

25. Nordman, C. J and Pasquier-Doumer, L (2014) Transitions in a West African Labour Market: The Role of Family Networks. IZA Discussion Paper No. 8349

26. Portes, and Alejandro, ed. (1998) "Social Capital: Its Origins and Applications in Contemporary Sociology." Annual Review of Sociology 24: 1-24.

27. Putnam, R.D. (ed.) (2002), Democracies in Flux: The Evolution of Social Capital in Contemporary Society. Oxford: Oxford University Press.

28. The Quality Assurance Agency, QAA (2019) The UK Quality Code for Higher Education. Canterbury: University of Kent

29. Woolcock, M. \& D. Narayan (2000) 'Social capital: Implications for development theory, research and policy', World Bank Research Observer 15 (2): 225-249.

30. Woolcock, M. (1998) 'Social capital and economic development: Toward a theoretical synthesis and policy framework', Theory and Society 27 (2): 151-208.

31. Turok, B (1981) Control in the Parastatal Sector of Zambia. The Journal of Modern African Studies, 19, pp 421-445.

32. Wanberg, C. R., Zhu, J., \& vn Hooft, E. A. J (2010) The job search grind: Perceived progress, self-reactions, and self-regulation of search effort. Academy of Management Journal, 53(4), 788-807 